\title{
PENGARUH CITRA MEREK DAN KEPERCAYAAN MEREK TERHADAP KEPUASAN PELANGGAN SERTA DAMPAKNYA TERHADAP LOYALITAS MEREK SEPEDA MOTOR MEREK HONDA
}

\author{
NURFADILA \\ MASKURI SUTOMO \\ ASRIADI \\ Jurusan Manajemen, Fakultas Ekonomi, Universitas Tadulako \\ Email: Nurfadila569.yahoo.com
}

\begin{abstract}
Independent variables used in this study are brand image and brand trust, while the dependent variable is customer satisfaction and brand loyalty. The type of research used in this research is descriptive causal method. Samples used in this study were as many as 97 respondents with the form of sampling using techniques Purposive Sampling and Accidental Sampling. Data analysis method used in this research is path analysis method. Result of research indicate that brand image influence to customer satisfaction, brand trust influence to customer satisfaction, brand image does not influence to brand loyalty, brand trust influence to brand loyalty and customer satisfaction influence to brand loyalty.
\end{abstract}

Keywords: Brand Image, Brand Trust, Custome satisfaction, Brand loyalty.

\begin{abstract}
ABSTRAK
Variabel independen yang digunakan dalam penelitian ini adalah citra merek dan kepercayaan merek, sedangkan variabel dependen adalah kepuasan pelanggan dan loyalitas merek. Jenis penelitian yang digunakan dalam penelitian ini adalah metode deskriptif kausal. Sampel yang digunakan pada penelitian ini yaitu sebanyak 97 responden dengan bentuk pengambilan sampel menggunakan teknik Purposive Sampling dan Accidental Sampling. Metode analisis data yang digunakan dalam penelitian ini adalah metode path analysis. Hasil penelitian menunjukkan bahwa citra merek berpengaruh terhadap kepuasan pelanggan, kepercayaan merek berpengaruh terhadap kepuasan pelanggan, citra merek tidak berpengaruh terhadap loyalitas merek, kepercayaan merek berpengaruh terhadap loyalitas merek dan kepuasan pelanggan berpengaruh terhadap loyalitas merek.
\end{abstract}

Kata Kunci: Citra Merek, Kepercayaan Merek, Kepuasan Pelanggan, Loyalitas Merek.

\section{PENDAHULUAN}

Dealer sepeda motor di Kota Palu telah mengalami perkembangan yang pesat selama beberapa tahun terakhir. Pembukaan dealer motor seperti Honda Anugerah Perdana serta dealer lainnya mendorong bisnis kendaraan roda dua di Kota Palu. Kondisi ini memicu masyarakat khususnya kaum muda untuk semakin sadar akan kendaraan sepeda motor yang mereka gunakan.

Honda Anugerah Perdana adalah salah satu dealer yang berusaha menjawab kebutuhan dan keinginan masyarakat, dealer tersebut berlokasi di jalan Yos Sudarso Palu Timur. Honda juga merupakan salah satu merek sepeda motor yang digemari oleh sebagian masyarakat baik digunakan sebagai kendaraan pribadi maupun kendaraan yang dikomersilkan.

Loyalitas merek merupakan suatu konsep yang sangat penting dalam strategi pemasaran. Keberadaan konsumen yang loyal pada merek sangat diperlukan agar perusahaan dapat bertahan. Loyalitas merek sebagai suatu ukuran keterkaitan pelanggan kepada sebuah merek yang mampu memberikan gambaran tentang mungkin tidaknya seorang pelanggan beralih ke merek lain yang ditawarkan oleh kompetitor, terutama jika pada merek tersebut didapati adanya perubahan, baik menyangkut harga ataupun atribut lainnya Aaker (2009:91). 
Konsumen yang loyal terhadap merek sepeda motor merek Honda berkomitmen pada produk sepeda motor merek Honda dan tidak akan menggantinya dengan merek lain. Pelanggan mengikuti perkembangan terkait dengan produk seperti layanan fitur atau produk terbaru yang ditawarkan sepeda motor merek Honda serta konsumen juga merekomendasikan merek sepeda motor merek Honda kepada orang lain. Penelitian ini adalah untuk melakukan pengujian langsung maupun tidak langsung seperangkat variabel bebas (eksogen) terhadap variabel terikat (endogen), seberapa besar pengaruhnya, serta untuk menelusuri mekanisme (jalur-jalur) pengaruh antara variabel citra merek dan kepercayaan merek terhadap kepuasan pelanggan serta dampaknya terhadap loyalitas merek. Mencapai tujuan penjualan yang maksimal masing-masing penjualan otomotif menyiapkan beberapa strategi. Salah satu strategi persaingan yang seringkali dilakukan oleh pihak perusahaan otomotif strategi memunculkan produk dengan keunggulan tertentu yang dapat diterima oleh pasar. Hal ini dimungkinkan karena sepeda motor merupakan salah satu produk yang cukup menjanjikan keuntungan bagi pelaku bisnis sebagai angkutan alternatif. Penelitian ini bertujuan untuk mengetahui dan menganalisa: pengaruh citra merek terhadap kepuasan pelanggan sepeda motor merek Honda, pengaruh kepercayaan merek terhadap kepuasan pelanggan sepeda motor merek Honda, pengaruh citra merek terhadap loyalitas merek sepeda motor merek Honda, pengaruh kepercayaan merek terhadap loyalitas merek sepeda motor merek Honda, pengaruh kepuasan pelanggan terhadap loyalitas merek sepeda motor merek Honda.

\section{KAJIAN LITERATURE}

\section{Pengertian Citra Merek}

Kotler dan Keller (2009:258) merek adalah nama, istilah, tanda, lambang, kombinasi atau desain, yang dimaksudkan untuk mengidentifikasi barang atau jasa dari penjual dan mendeferensiasikan dari produk pesaing. Merek merupakan salah satu faktor penting dalam kegiatan pemasaran karena kegiatan memperkenalkan dan menawarkan produk dan jasa tidak terlepas dari merek yang dapat diandalkan. Hal ini berarti bahwa merek tidak berdiri sendiri. Merek harus sesuai dengan komponen proses pemasaran lainnya Surachman (2008:1). Selain itu, pengertian merek bukan sekedar sesuatu yang dapat menampilkan nilai fungsionalnya, melainkan juga dapat memberikan nilai tertentu dalam lubuk hati atau benak konsumen Surachman (2008:2).

Menurut Kotler \& Keller (2013) pengukur citra merek dapat dilakukan berdasarkan pada aspek sebuah merek yaitu:

a) Kekuatan (Strengthness)

Kekuatan asosiasi merek adalah seberapa kuat seseorang terpikir tetntang informasi suatu Brand diantaranya logo dan nama Brand, serta bagaimana memproses segala informasi yang diterima konsumen dan bagaiman informasi tersebut dikelola oleh data sensoris di otak sebagai bagian dari Brand Image. Ketika konsumen secara aktif memikirkan dan menguraikan arti informasi pada suatu produk atau jasa maka akan tercipta asosiasi yang semakin kuat pada ingatan konsumen. Konsumen memandang suatu objek stimuli sensasi-sensasi yang mengalir lewat kelima indera: mata, telinga, hidung, kulit dan lidah. Namun demikian, setiap konsumen mengikuti, mengatur dan menginterprestasikan data sensoris ini menurut cara masing-masing. Persepsi tidak hanya tergantung pada stimulasi fisik tetapi juga pada stimulasi yang berhubungan dengan lingkungan sekitar dan keadaan individu tersebut.

\section{b. Keunikan (Uniqueness)}

Sebuah merek haruslah unik dan menarik sehingga produk tersebut memiliki ciri khas dan sulit untuk ditiru oleh para produsen pesaing. Melalui keunikan suatu produk maka akan memberikan kesan yang cukup membekas terhadap ingatan pelanggan akan keunikan Brand atau merek produk tersebut yang membedakannya dengan produk sejenis lainnya. Sebuah merek yang memiliki ciri khas haruslah dapat melahirkan keinginan pelanggan mengetahui lebih jauh dimensi merek yang terkandung 
didalamnya. Merek hendaknya mampu menciptakan motivasi pelanggan untuk mulai mengonsumsi produk dan menciptakan kesan yang baik bagi merek tersebut. Keunikan merek ini terdapat pada ciri khas merek baik produk maupun jasanya, serta produk yang sulit untuk ditiru.

\section{c. Keunggulan (Favorable)}

Keunggulan asosiasi merek dapat membuat konsumen percaya bahwa atribut dan manfaat yang diberikan oleh suatu merek dapat memuaskan kebutuhan dan keinginan konsumen sehingga menciptakan sikap yang positif terhadap merek tersebut. Tujuan akhir dari setiap konsumsi yang dilakukan oleh konsumen adalah mendapatkan kepuasan akan kebutuhan dan keinginan mereka. Adanya kebutuhan dan keinginan dalam diri konsumen melahirkan harapan, di mana harapan tersebut yang diusahakan oleh konsumen untuk dipenuhi melalui kinerja produk dan merek yang dikonsumsinya. Apabila kinerja produk atau merek melebi harapan, maka konsumen akan puas, dan demikian juga sebaliknya. Dapat disimpulkan bahwa keunggulan asosiasi merek terdapat pada manfaat produk, tersediannya banyak pilihan untuk memenuhi kebutuhan dan keinginan, harga yang ditawarkan bersaing dan kemudahan mendapatkan produk yang dibutuhkan serta nama perusahaan yang bonafit juga mampu menjadi pendukung merek tersebut.

Menurut Ratri (2007:50) citra merek sering terkonseptualisasi sebagai sebuah koleksi dari semua asosiasi yang berhubungan dengan sebuah merek yang terdiri dari:

1. Faktor fisik, karakteristik fisik dari merek tersebut, seperti desain kemasan, logo, nama merek, fungsi, dan kegunaan produk dari merek itu.

2. Faktor psikologis, dibentuk oleh emosi, kepercayaan, nilai, kepribadian yang dianggap oleh konsumen menggambarkan produk dari merek tersebut. Citra merek sangat erat kaitannya dengan apa yang orang pikirkan, rasakan terhadap suatu merek tertentu, sehingga dalam citra merek faktor psikologis lebih banyak berperan dibandingkan faktor fisik dari merek tersebut.

Menurut Joseph Plummer dalam Ratri (2007:54) citra merek terdiri dari tiga komponen, yaitu:

1. Atribut produk (Product attributes) yang merupakan hal-hal yang berkaitan dengan merek tersebut sendiri, seperti kemasan, isi produk, harga, rasa, dan lain-lain.

2. Keuntungan konsumen (Consumer benefits) yang merupakan kegunaan produk dari merek tersebut.

3. Kepribadian merek (Brand personality) merupakan asosiasi yang mengenai kepribadian sebuah merek apabila merek tersebut adalah manusia.

\section{Pengertian Kepercayaan Merek}

Kepercayaan merek sebagai dugaan dengan keyakinan akan realibilitas dan niat suatu merek dalam situasi yang melibatkan resiko bagi konsumen. Kepercayaan adalah dugaan atau harapan bahwa merek tersebut dapat diandalkan untuk berperilaku murah hati dan responsif terhadap kebutuhan seseorang. Bagi perusahaan, kepercayaan merek merupakan sebuah target yang penting untuk dicapai. Kelangsungan hidup baik perusahaan maupun produk tersebut sangat bergantung pada kepercayaan konsumen.

Menurut Chi dan Chiou (2009) Kepercayaan merek berarti konsumen-konsumen yang percaya bahwa suatu merek spesifik akan menawarkan suatu produk yang sangat dapat diandalkan, seperti fungsi yang lengkap, jaminan kualitas, dan service setelah penjualan kepada mereka.

Menurut Chaudhuri dan Holbrook (2001) menilai kepercayaan terhadap merek sebagai bentuk proses keterlibatan yang telah di duga sepenuhnya dan disadari secara mendalam. Kepercayaan terhadap suatu merek akan menimbulkan kesetiaan konsumen pada merek tersebut. Kepercayaan terhadap suatu merek akan muncul sebagai kunci utama terhadap awal kesetiaan terhadap suatu merek sesuai dengan konsep hubungan pemasaran. 
Menurut Chaudhuri \& Holbrook (2001), menggunakan empat indikator untuk mengukur variabel kepercayaan merek yaitu:

1. Kepercayaan (Trust) didefinisikan sebagai wujud dari konsumen mempercayai sebuah produk atau jasa melalui merek.

2. Dapat diandalkan (Rely) diartikan sebagai suatu tigkatan kepercayaan terhadap suatu produk atau jasa dapat diandalkan melalui karakteristik suatu merek.

3. Jujur (Honest) diartikan sebagai suatu tingkatan kepercayaan terhadap merek bahwa sebuah produk atau jasa merupakan produk atau jasa (merek) yang jujur.

4. Keamanan ( $\mathrm{Safe}$ ) didefinisikan sebagai tingkat keamanan yang dipercayai konsumen pada merek, produk, atau jasa.

Menurut Lau dan Lee (2000) kepercayaan adalah harapan dari pihak-pihak dalam sebuah transaksi dan resiko yang terkait dengan perkiraan dan perilaku terhadap harapan tersebut. Assael (1998:55) mengemukakan bahwa dalam mengukur kepercayaan terhadap merek diperlukan penentuan atribut dan keuntungan dari sebuah merek.

Prediktor penting kepercayaan pelanggan pada merek yang pada akhirnya akan mengarah pada pelanggan pada merek tersebut adalah karakteristik merek, karakteristik perusahaan, dan karakteristik hubungan pelanggan dengan merek (Tjahyadi, 2006:66).

\section{Karakteristik Merek (Brand Characteristic)}

Karakteristik merek memainkan peran yang vital dalam menentukan apakah pelanggan memutuskan untuk percaya pada suatu merek. Berdasarkan pada penelitian interpersonal, individuindividu yang dipercaya didasarkan pada reputation, predictability, dan competence dari individu tersebut (Tjahyadi, 2006:73). Konteks hubungan pelanggan merek, kepercayaan pelanggan dibangun berdasarkan pada reputasi merek, prediktabilitas merek, dan kompetensi merek. Penjelasan dari tiga karakteristik merek dapat ditunjukkan sebagai berikut:

a. Reputasi Merek (Brand Reputation)

Brand reputation berkenaan dengan opini dari orang lain bahwa merek itu baik dapat diandalkan (Reliable). Reputasi merek dapat dikembangkan bukan saja melalui advertising dan public relation, tapi juga dipengaruhi oleh kualitas dan kinerja produk. Pelanggan akan mempersepsikan bahwa sebuah merek memiliki reputasi baik. Jika, sebuah merek yang dapat memenuhi harapan mereka, maka reputasi merek yang baik tersebut akan memperkuat kepuasan pelanggan.

b. Prediktabilitas Merek (Brand Predictability)

Brand predictability berkenaan dengan kemampuan suatu kelompok untuk memprediksi perilaku dari kelompok lain. Brand predictability adalah merek yang memungkinkan pelanggan untuk mengharapkan bagaimana sebuah merek akan memiliki performance pada setiap pemakaian. Predictability mungkin karena tingkat konsistensi dari kualitas produk. Brand Predictability dapat meningkatkan keyakinan konsumen karena mengetahui bahwa tidak ada sesuatu yang tidak diharapkan akan terjadi ketika menggunakan merek tersebut. Karena itu, Brand predictability akan meningkatkan kepercayaan terhadap merek karena Predictability menciptakan ekspektasi positif.

c. Kompetensi Merek (Brand Competence)

Brand competence adalah merek yang mempunyai kemampuan untuk menyelesaikan permasalahan yang dihadapi oleh pelanggan, kemampuan berkaitan dengan keahlian dengan karakteristik yang memungkinkan suatu kelompok memiliki pengaruh dalam suatu wilayah tertentu. Ketika diyakini bahwa sebuah merek itu mampu untuk menyelesaikan permasalahan dalam diri pelanggan, maka pelanggan tersebut mungkin berkeinginan untuk menyakini merek tersebut. 


\section{Karakteristik Perusahaan (Company Characteristics)}

Karakteristik perusahaan juga dapat mempengaruhi tingkat kepercayaan pelanggan pada sebuah merek. Pengetahuan konsumen terhadap perusahaan kemungkinan akan mempengaruhi penilaiaanya terhadap merek perusahaan. Karakteristik perusahaan yang berpengaruh terhadap kepercayaan pelanggan pada sebuah merek adalah kepercayaan pelanggan terhadap perusahaan, reputasi perusahaan, motof-motif dari perusahaan yang dipersepsikan, dan integritas perusahaan yang dipersepsiakan Tjahyadi (2006:73).

a. Kepercayaan Terhadap Perusahaan ( Trusth In The Company)

Kasus perusahaan dalam mereknya, perusahaan merupakan entitas terbesar dan merek merupakan entitas terkecil dari entitas terbesar tersebut. Sehingga, pelanggan yang percaya terhadap perusahaan kemungkinan percaya terhadap mereknya.

b. Reputasi Perusahaan (Company Reputation)

Ketika pelanggan mempersepsikan opini orang lain bahwa perusahaan dikenal adil dan juga jujur, maka pelanggan akan merasa lebih aman dalam memperoleh dan menggunakan merek perusahaan. Dalam konteks saluran pemasaran, ketika perusahaan dinilai memiliki reputasi yang baik, maka pelanggan kemungkinan besar akan percaya pada pengecer dan vendor.

c. Motivasi Perusahaan (Company Perceived Motives)

Perusahaan tentu ingin mendapatkan hal yang diinginkannya dan dicita-citakannya. Berupaya dengan sekuat tenaga untuk menjadikan perusahaannya menjadi perusahaan yang besar. Konteks merek, ketika pelanggan mempersepsikan suatu perusahaan layak dipercaya dan bertindak sesuai dengan kepentingan mereka, maka pelanggan akan mempercayai merek perusahaan.

d. Integritas Perusahaan (Company Integrity)

Integritas perusahaan merupakan persepsi pelanggan yang melekat pada sekumpulan dari prinsip-prinsip yang dapat diterima. Perusahaan yang memiliki integritas tinggi tergantung pada konsistensi dari tindakannya dimasa lalu, komunikasi yang akurat tentang perusahaan dari kelompok lain, keyakinan bahwa perusahaan memiliki sense of justice yang kuat serta tindakannya sesuai dengan janji-janjinya. Jika perusahaan dipersepsikan memiliki integritas tersebut, maka kemungkinan merek perusahaan akan dipercaya oleh pelanggan.

\section{Karakteristik Pelanggan Merek (Consumer Brand Characteristics )}

Suatu hubungan tidak satu arah, setiap kelompok saling mempengaruhi dalam hubungannya dengan kelompok lain. Sehingga, karakteristik pelanggan merek dapat mempengaruhi kepercayaan pelanggan terhadap merek. Karakteristik dalam hubungan pelanggan dengan merek mencakup kesamaan (similarity) antara self-concept pelanggan dengan citra merek, kesukaan pelanggan terhadap merek, pengalaman pelanggan, kepuasan pelanggan, serta dukungan dari rekan (peer support).

1. Kesamaan antara konsumen dengan merek (Similarity Between Consumer Self- Concept dan Brand Personality )

Penelitian dalam hubungan interpersonal menunjukkan bahwa simililaritas dari karakteristik dua kelompok dapat memberikan kecendrungan tubuhnya kepercayaan. Seseorang pelanggan akan mengevaluasi dan menilai sebuah merek jika sebuah merek memiliki kesamaan dengan dirinya sendiri. Jika atribut atau personality fisik merek dinilai sama dengan self-image pelanggan, maka pelanggan kemungkinan untuk mempercayai merek tersebut.

2. Merek Kesukaan (Liking The Brand)

Mengawali suatu hubungan, suatu kelompok harus disenangi oleh kelompok lain. Pemasaran konsumen, maka pelanggan tersebut kemungkinan besar akan mempercayai merek itu.

3. Pengalaman Masa Lalu (Experience With The Brand)

Seperti yang telah dijelaskan sebelumnya, konsumen belajar dari pengalaman masa lalunya, dan perilaku dimasa lalunya. Ketika konsumen memperoleh pengalaman lebih dengan sebuah 
merek, maka mereka akan memahami merek dengan lebih baik menumbuhkan kepercayaan lebih terhadap merek tersebut.

4. Kepuasan Terhadap Merek (Satisfaction With The Brand)

Kepuasan terhadap sebuah merek dapat didefenisikan sebagai hasil dari evaluasi subjektif bahwa merek alternatif yang dipilih memenuhi atau melampaui ekspektasi konsumen. Pemenuhan janji (Promise) merupakan antecedent bagi kepercayaan dalam hubungan pemasaran industri. Ketika pelanggan puas dengan suatu merek setelah menggunakan merek tersebut, maka pada situasi yang sama kepuasan pada suatu merek juga akan terpenuhi. Ketika suatu merek telah mempertahankan janjinya, maka pelanggan kemungkinan besar akan mempercayai merek tersebut.

e. Pengaruh Individu Lainnya (peer support)

Faktor yang penting dalam menentukan perilaku indiviu adalah pengaruh individu lainnya, dan menyatakan bahwa pengaruh sosial merupakan faktor yang penting dalam menentukan perilaku konsumen. Karena itu, pelanggan kemungkinan akan percaya terhadap merek yang mana orang/pihak lain yang berarti bagi mereka memperlihatkan kepercayaannya pada suatu merek.

\section{Pengertian Kepuasan Pelanggan}

Tjiptono (2014: 353) Kepuasan adalah respon atau tanggapan konsumen mengenai pemenuhan kebutuhan. Kepuasan merupakan penilaiaan mengenai ciri atau keistimewaan produk atau jasa, atau produk itu sendiri, yang menyediakan tingkat kesenangan konsumen berkaitan dengan memenuhan kebutuhan konsumsi konsumen.

Kotler dan Keller (2009: 177) kepuasaan pelanggan adalah perasaan senang atau kecewa sesesorang terhadap suatu produk setelah ia membandingkan hasil/prestasi produk yang dipikirkan terhadap kinerja/hasil produk yang diharapkan. Jika kinerja memenuhi harapan, maka itu artinya pelanggan puas. Tetapi jika kinerja melebihi harapan pelanggan, maka pelanggan amat puas atau senang.

Menurut Simamora (2003: 18) kepuasan pelanggan adalah hasil pengalaman terhadap produk. Ini adalah sebuah perasaan pelanggan setelah membandingkan antara harapan (prepurchase expectation) dengan kinerja aktual (actual performance). Kepuasan konsumen tingkat perasaan konsumen setelah membandingkan antara apa yang dia terima dan harapannya.

\section{Mengukur Kepuasan Pelanggan}

Menurut Tjiptono 2008: 175) kepuasan merupakan ukuran kinerja "produk total" sebuah organisasi dibandingkan serangkaian keperluan pelanggan (Costumer requirements). Kepuasan pelanggan bukanlah konsep absolut, melainkan relatif atau tergantung pada apa yang diharapkan pelanggan. Selain itu, Tjiptono (2008: 175) menyebutkan prinsip dasar yang melandasi pentingnya pengukuran kepuasan pelanggan adalah "doing best what matters most costumers" yaitu melakukan yang terbaik aspek - aspek terpenting bagi pelanggan.

Menurut Dutka (1994: 41), terdapat tiga dimensi dalam mengukur kepuasan pelanggan secara universal yaitu 1). Attributes related to product yaitu dimensi kepuasan yang berkaitan dengan atribut dari produk seperti penetapan nilai yang didapatkan dengan harga, kemampuan produk menentukan kepuasan, benefit dari produk tersebut. 2). Attributes related to service yaitu dimensi kepuasan yang berkaitan dengan atribut dari pelayanan misalnya dengan garansi yang dijanjikan, proses pemenuhan pelayanan atau pengiriman, dan proses penyelesaian masalah yang diberikan. 3). Attributes related to purchase yaitu dimensi kepuasan yang berkaitan dengan atribut dari keputusan untuk membeli atau tidaknya dari produsen seperti kemudahan mendapat informasi, kesopanan karyawan dan juga pengaruh reputasi perusahaan.

Fornell (1996), bahwa sejumlah studi menunjukkan bahwa ada tiga aspek penting yang perlu dalam kerangka pengukuran kepuasan pelanggan, yakni : (1) kepuasan general atau keseluruhan (overall satisfaction); (2) konfirmasi harapan (confirmation of expectation), yakni tingkat kesesuaian antara 
kinerja dengan ekspektasi; dan (3) perbandingan situasi ideal (comparison to ideal), yaitu kinerja produk dibandingkan dengan produk ideal menurut persepsi konsumen.

Setiap perusahaan yang memperhatikan kepuasan konsumen akan dapat memperoleh beberapa manfaat pokok yaitu:

1. Reputasi perusahaan semakin positif dimata masyarakat pada umumnya dan pelanggan pada khususnya.

2. Dapat mendorong terciptanya loyalitas pelanggan.

3. Memungkinkan terciptanya rekomendasi dari mulut ke mulut yang menguntungkan bagi perusahaan sehingga semakin banyak orang yang akan membeli.

4. Meningkatkan volume penjualan dan keuntungan.

5. Hubungan antara perusahaan dan para pelanggannya menjadi harmonis.

6. Mendorong setiap anggota organisasi untuk bekerja dengan tujuan serta kebanggaan yang lebih baik.

7. Menekan gaya melayani sebagai dampak faktor familiaritas dan relasi khusus dengan pelanggan.

8. Terbukanya peluang melakukan penjualan silang (cross selling product).

Kotler dan Keller (2012) Ada empat metode yang sering digunakan dalam mengukur kepuasan pelanggan:

1) Sistem keluhan dan saran

Setiap oraganisasi yang beroriantasi pada pelanggan wajib memberikan kesempatan seluas-luasnya bagi para pelanggan untuk menayampaikan saran, kritik, pendapat dan keluahan mereka. Media yang digunakan biasa berupa, Kotak saran di lokasi-lokasi strategis, Kartu pos berprangko, Saluran telepon bebas pulsa, Website, Email, Fax, Blog, dan lain - lain.

2) Ghost Shopping

Yaitu salah satu bentuk riset observasi partisipatoris yang memakai jasa orang - orang yang 'menyamar' sebagai pelanggan perusahaan dan pesaing sembari mengamati secara rinci aspek aspek layanan dan kualitas produrk dan ghost shopping pada saat ini, sudah banyak dilakukan oleh perusahaan-perusahaan yang bergerak dibidang penjualan dan pelayanan, seperti supermarket, perusahaan distributor, perbankan dan lain-lain.

3) Lost Costumer analysis

Yaitu menghubungi atau mewawancarai pelanggan yang telah bersalin pemasok dalam rangka memahami penyebabnya dan melakukan perbaikan layanan.

4) Survei Kepuasan pelanggan

Umumnya sebagian besar penelitian mengenai kepuasan pelanggan menggunakan metode survey, baik via pos, Telepon, Email, Website, Blog, Maupun tatap muka langsung. Melalui survey Perusahaan akan memperoleh tanggapan dan umpan balik langsung dari pelanggan dan juga memberi nilai positif bahwa perusahaan menaruh perhatian pada mereka.

\section{Faktor-Faktor Yang Mempengaruhi Kepuasaan Pelanggan}

Lupiyoadi (2001: 158) menyebutkan lima faktor utama yang perlu diperhatikan dalam kaitannya dengan kepuasan konsumen antara lain:

a. Kualitas Produk. Konsumen akan puas bila hasil evaluasi mereka menunjukkan bahwan produk yang mereka gunakan berkualitas. Produk dikatakan berkualitas bagi seseorang, jika produk itu dapat memenuhi kebutuhanya. Kualitas produk ada dua yaitu eksternal dan internal. Salah satu kualitas produk dari faktor eksternal adalah citra merek.

b. Kualitas Pelayanan. Konsumen akan merasa puas bila mendapatkan pelayanan yang baik atau yang sesuai dengan harapan.

c. Emosional. Konsumen merasa puas ketika orang memuji dia karena menggunakan merek yang mahal. 
d. Harga. Produk yang mempunyai kualitas yang sama tetapi menetapkan harga yang relatif murah akan memberikan nilai yang lebih tinggi.

e. Biaya. Konsumen yang tidak perlu mengeluarkan biaya tambahan atau tidak perlu membuang waktu untuk mendapatkan suatu produk atau jasa cenderung puas terhadap produk atau jasa tersebut.

\section{Ciri-Ciri Konsumen Yang Puas}

Kotler dan Amstrong (2009) menyatakan ciri-ciri konsumen yang puas sebagai berikut:

1) Loyal terhadap produk. Konsumen yang terpuaskan cenderung akan menjadi loyal. Konsumen yang puas terhadap produk yang dikonsumsinya akan mempunyai kecendrungan untuk membeli ulang karena adanya keinginan untuk mengulang pengalaman yang baik dan menghindari pengalaman yang buruk.

2) Adanya komunikasi dari mulut ke mulut yang bersifat positif. Kepuasan adalah merupakan faktor yang mendorong adanya kominikasi dari mulut ke mulut (word of mouth communication) yang bersifat positif. Hal ini dapat berupa rekomendasi kepada calon konsumen yang lain dan mengatakan hal-hal yang baik mengenai produk dan perusahaan yang menyediakan produk.

3) Perusahaan menjadi pertimbangan utama ketika membeli merek lain. Ketika konsumen ingin membeli produk yang lain, maka perusahaan yang telah memberikan kepuasan kepadanya akan menjadi pertimbangan yang utama.

\section{Elemen Kepuasan Konsumen}

Wilkie (1994: 206) menyatakan bahwa terdapat 4 elemen dalam kepuasan konsumen yaitu :

1) Expectations. Harapan konsumen terhadap suatu barang atau jasa telah dibentuk sebelum konsumen membeli barang atau jasa tersebut. Pada saat proses pembelian dilakukanan, konsumen berharap bahwa barang atau jasa yang mereka terima sesuai dengan harapan, keinginan dan keyakinan mereka. Barang atau jasa yang sesuai dengan harapan konsumen akan menyebabkan konsumen merasa puas.

2) Performance. Pengalaman konsumen terhadap kinerja aktual barang atau jasa ketika digunakan tanpa diperngaruhi oleh harapan mereka. Ketika kinerja actual barang atau jasa berhasil maka konsumen akan merasa puas.

3) Comparison. Hal ini dilakukan dengan membandingkan harapan kinerja barang atau jasa sebelum membeli dengan persepsi kinerja aktual barang atau jasa tersebut. Konsumen akan merasa puas ketika harapan sebelum pembelian sesuai atau melebihi perepsi mereka terhadap kinerja aktual produk.

4) Confirmation/disconfirmation. Harapan konsumen dipengaruhi oleh pengalaman mereka terehadap penggunaan merek dari barang atau jasa yang berbeda dari orang lain. Confirmation terjadi bila harapan sesuai dengan kinerja aktual produk. sebaliknya disconfirmation terjadi ketika harapan lebih tinggi atau lebih rendah dari kinerja aktual produk. konsumen akan merasa puas ketika tejadi confirmation / discofirmation.

\section{Pengertian Loyalitas Merek}

Menurut Setiadi (2003), oyalitas merek dapat didefinisikan sebagai sikap menyenangi suatu merek yang direpresentasikan dalam pembelian yang konsisten terhadap merek itu sepanjang waktu. Pada loyalitas merek, tidak ada lagi merek yang dipertimbangkan untuk dibeli selain merek produk yang sering dibelinya.

Loyalitas merek adalah komitmen instrinsik untuk melakukan pembelian berulang terhadap suatu merek tertentu. Peter \& Olson (2002), Brand Loyalty atau loyalitas merek didefinisikan sebagai tingkat dimana konsumen mempunyai sikap positif terhadap merek, mempunyai komitmen terhadap merek itu, dan memiliki niat untuk tetap melakukan pembelian secara kontinyu. Loyalitas merek dipengaruhi secara langsung oleh kepuasan atau ketidakpuasan konsumen terhadap merek yang terakumulasi dalam jangka waktu tertentu. 
Loyalitas merek adalah suatu kondisi dimana seorang pelanggan menunjukkan sikap positif terhadap suatu merek, mempunyai komitmen pada merek tertentu dan berniat untuk terus membelinya di masa mendatang Mowen dan Minor (2002). Loyalitas merek berkaitan erat dengan pengalaman dalam menggunakan merek. Jadi terjadinya loyalitas merek pada konsumen disebabkan oleh adanya pengaruh kepuasan atau ketidakpuasan dengan suatu merek yang terakumulasi secara terus-menerus disamping adanya persepsi tentang kualitas produk. Konsumen yang loyal terhadap suatu merek produk akan melakukan pembelian ulang terhadap produk dengan merek yang sama. Loyalitas merek yang dimaksud dalam penelitian ini adalah kesetiaan konsumen untuk tetap mau memakai sepeda motor merek Honda meskipun belakangan ini banyak model sepeda motor yang dikeluarkan.

Adapun indikator dalam variabel dependen antara lain :

a. Pelanggan berkomitmen pada produk sepeda motor merek Honda dan tidak akan menggantinya dengan merek lain.

b. Pelanggan merekomendasikan merek sepeda motor merek Honda kepada orang lain.

c. Pelanggan mengikuti perkembangan terkait dengan produk seperti layanan fitur atau produk terbaru yang ditawarkan sepeda motor merek Honda.

Schiffman dan Kanuk (dikutip oleh Sasongko dan Santoso, 2008) menyatakan bahwa dimensi loyalitas merek terbagi dalam 2 dimensi yaitu:

1. Attitudinal Loyalty (pengukuran sikap) Attitudinal loyalty meliputi 3 bagian, yaitu:

a) Cognitive Loyalty

Loyalitas ini merupakan representasi dari apa yang dipercayai oleh konsumen. Dimensi kognitif berisikan persepsi, kepercayaan dan stereotype seorang konsumen mengenai suatu merek.

b) Affective Loyalty

Loyalitas ini didasarkan pada perasaan dan komitmen konsumen terhadap suatu merek. Konsumen memiliki kedekatan emosional terhadap merek tersebut. Loyalitas afektif ini merupakan fungsi dari perasaan dan sikap konsumen terhadap sebuah merek seperti rasa senang, suka, dan gemar. Pengungkapan perasaaan ini dapat dengan atau tanpa membandingkan dengan merek lain. Jika konsumen memiliki sikap yang positif terhadap merek, maka dalam diri konsumen akan berkembang loyalitas afektif.

c) Conative Loyalty/behavioral intent

Loyalitas konatif merupakan batas antara attitudinal loyalty dan behavioral loyalty yang direpresentasikan melalui kecenderungan perilaku konsumen untuk menggunakan merek yang sama dimasa yang akan datang. Loyalitas konatif merupakan tingkah laku yang masih bersifat intent, belum tampak dalam tingkah laku nyata.

a) Behavioral Loyalty (pengukuran perilaku)

Meliputi action loyalty, yang didefinisikan sebagai tingkah laku membeli ulang suatu merek oleh seorang konsumen terhadap kategori produk tertentu. Tingkah laku seorang konsumen yang loyal tercermin melalui frekuensi dan konsistensi pembelian suatu merek. Selain itu, salah satu aktualisasi loyalitas konsumen ditunjukkan oleh tindakan merekomendasikan dan mempromosikan merek tersebut kepada pihak lain. Peningkatan profitabilitas itu terlalu indah untuk menjadi kenyataan, perhatikan beberapa faktor. Menurut Griffin (2005:11-12) loyalitas yang meningkat dapat meningkat dapat menghemat biaya perusahaan sedikitnya dienam bidang antara lain:

1. Biaya pemasaran menjadi berkurang.

2. Biaya transaksi menjadi lebih rendah.

3. Biaya perputaran menjadi berkurang.

Keberhasilan cross-selling menjadi meningkat, menyebabkan pangsa pelanggan menjadi lebih besar.

4. Pemberitahuan dari mulut kemulut menjadi lebih positif.

5. Biaya kegagalan menjadi menurun. 
Maka dari berbagai teori diatas, dapat disimpulkan bahwa loyalitas merek merupakan suatu konsep yang sangat penting dalam strategi pemasaran. Keberadaan konsumen yang loyal pada merek sangat diperlukan agar perusahaan dapat bertahan hidup. Loyalitas dapat diartikan sebagai suatu komitmen yang mendalam untuk melakukan pembelian ulang produk atau jasa yang menjadi preferensinnya secara konsisten pada masa yang akan datang dengan cara membeli ulang merek yang sama meskipun ada pengaruh situasional dan usaha pemasaran yang dapat menimbulkan perilaku peralihan.

\section{Kerangka Pemikiran}

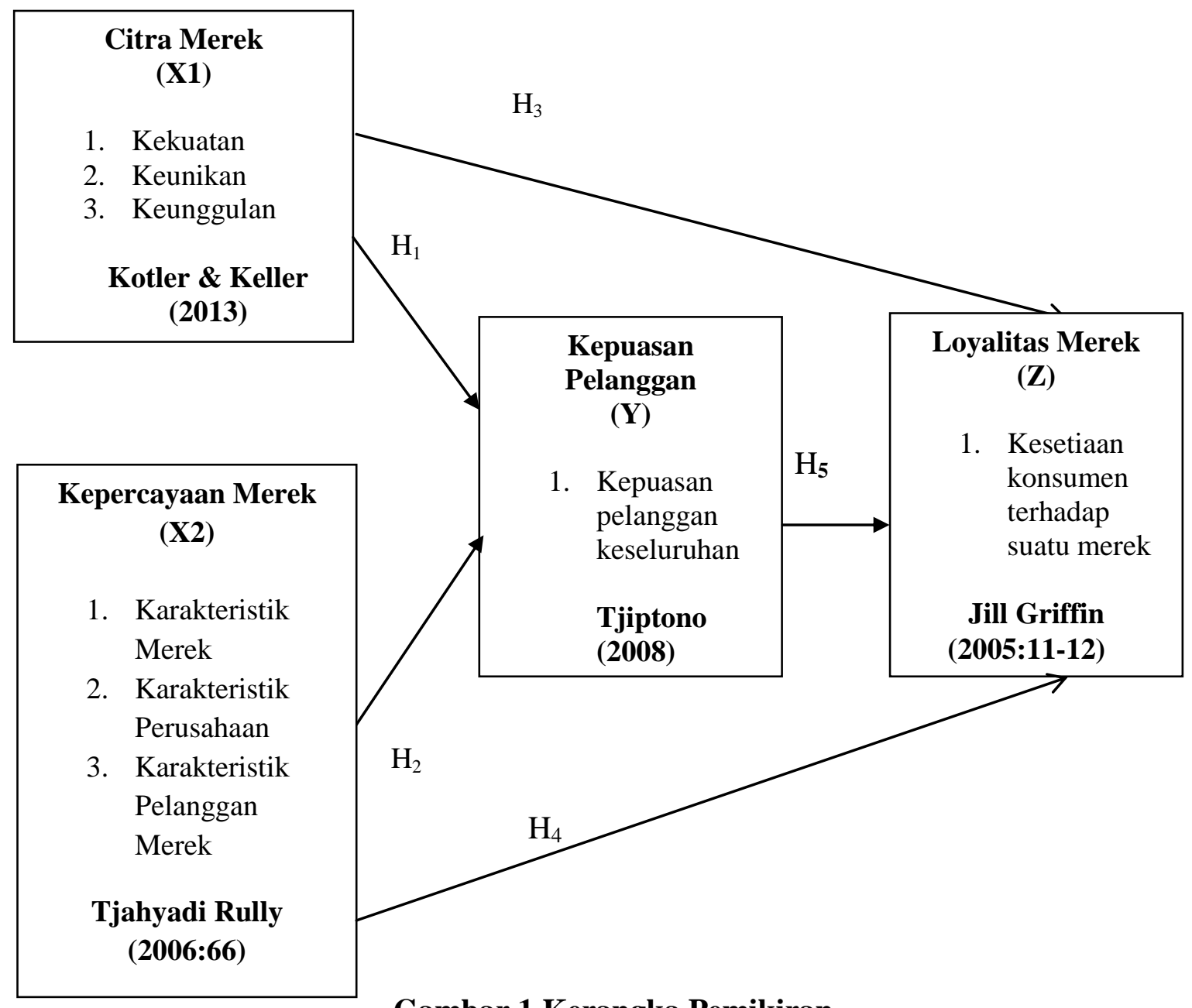

Gambar 1 Kerangka Pemikiran

Berdasarkan kerangka berpikir di atas dapat disusun beberapa hipotesis sebagai berikut:

1. Terdapat pengaruh Citra Merek terhadap Kepuasan Pelanggan Sepeda Motor Merek Honda.

2. Terdapat pengaruh Kepercayaan Merek terhadap Kepuasan Pelanggan Sepeda Motor Merek Honda.

3. Terdapat pengaruh Citra Merek terhadap Loyalitas Merek Sepeda Motor Merek Honda.

4. Terdapat pengaruh Kepercayaan Merek terhadap Loyalitas Merek Sepeda Motor Merek Honda.

5. Terdapat pengaruh Kepuasan Pelanggan terhadap Loyalitas Merek Sepeda Motor Merek Honda.

\section{METODE PENELITIAN}

Penelitian ini merupakan jenis penelitian kausal dimana ditujukan untuk menganalisis hubungan sebab akibat antar variabel yaitu variabel-variabel citra merek, kepercayaan merek sebagai variabel bebas dan kepuasan pelanggan serta loyalitas merek sebagai variabel terikat. Sebagaimana 
dikemukakan oleh Sugiyono (2014:54) bahwa penelitian deskriptif adalah metode yang digunakan untuk menganalisa data dengan cara mendeskripsikan atau menggambarkan data yang telah terkumpul sebagaimana adanya tanpa bermaksud membuat kesimpulan yang berlaku untuk umum atau generalisasi”. Teknik pengambilan dan pengumpulan data yang dilakukan dengan cara: observasi, wawancara, kuesioner, dan dokumentasi. Populasi dalam penelitian ini adalah konsumen pengguna Sepeda Motor Merek Honda. Teknik pengambilan sampel untuk menentukan sampel yang akan digunakan dalam penelitian ini menggunakan Teknik non probability sampling, yaitu purposive sampling. Dikarenakan jumlah populasinya tidak diketahui secara pasti maka untuk menentukan besarnya sampel yaitu dengan menggunakan rumus Unknown Populations Frendy dalam Ekasari (2014: 98)

$$
\mathrm{n}=\frac{\mathrm{Z}^{2}}{4 \mu^{2}}
$$

Keterangan:

$\mathrm{n}=$ ukuran sampel

$\mathrm{Z}=$ tingkat keyakinan sampel yang dibutuhkan dalam penelitian, pada $\alpha=5 \%$ (derajat keyakinan ditentukan 95\%) maka $\mathrm{Z}=1,96$

$\mu=$ margin of error, tingkat kesalahan yang dapat ditolerir (ditentukan 10\%)

Menggunakan rumus diatas, maka diperoleh perhitungan sebagai berikut:

$$
\begin{aligned}
& \mathrm{n}=\frac{1,96^{2}}{4(0,1)^{2}} \\
& \mathrm{n}=96,4 \approx 97 \text { responden }
\end{aligned}
$$

\section{Analisis Jalur}

Riduwan dan Kuncoro (2007: 2) model analisis jalur path analysis digunakan untuk menganalisis pola hubungan antar variabel dengan tujuan untuk mengetahui pengaruh langsung maupun tidak langsung seperangkat variabel bebas (eksogen) terhadap variabel terikat (endogen) dan membicarakan hubungan sebab akibat.

persamaan struktural dalam model analisis jalur ini adalah sebagai berikut:

$\mathrm{Y}=\rho \mathrm{yx}_{1}+\rho \mathrm{yx}_{2}+\epsilon_{1}$

$Z=\rho z y+\epsilon_{2}$

\section{HASIL DAN PEMBAHASAN}

\begin{tabular}{|c|c|c|c|c|c|}
\hline \multirow{2}{*}{ Model } & \multicolumn{2}{|c|}{$\begin{array}{c}\text { Unstandardized } \\
\text { Coefficients }\end{array}$} & \multirow{2}{*}{$\begin{array}{c}\begin{array}{c}\text { Standardized } \\
\text { Coefficients }\end{array} \\
\text { Beta }\end{array}$} & \multirow{2}{*}{$\mathrm{t}$} & \multirow{2}{*}{ Sig. } \\
\hline & $\mathrm{B}$ & Std.Error & & & \\
\hline Citra Merek (X1) & 0.376 & 0.093 & 0.399 & 4.037 & 0.000 \\
\hline Kepercayaan Merek (X2) & 0.265 & 0.096 & 0.272 & 2.752 & 0.007 \\
\hline \multicolumn{6}{|c|}{$\begin{array}{lcc}\mathrm{R} & = & 0,591 \\
\mathrm{R} \text { Square } & =0,349 \\
\text { Adjusted R Square } & =0,335 \\
\text { Dependent Variabel: Kepuasan Pelanggan (Y) }\end{array}$} \\
\hline
\end{tabular}

Analisis Jalur ( Path Analysis )

Tabel 1

Hasil Regresi Persamaan Struktural Terhadap Kepuasan Pelanggan (Y)

Sumber: Data Primer Diolah

Pengaruh kesalahan pengganggu atau error variabel $\left(\rho \varepsilon_{1}\right)$ untuk persamaan struktural pertama diperoleh: 


$$
\begin{aligned}
& P \mathcal{E} 1=\sqrt{1-(R)^{2}} \\
& \sqrt{1}-0,591 \\
& =0,80667
\end{aligned}
$$

Persamaan struktural pertama diperoleh:

$$
\mathrm{Y}=0.399 \times 1,0,272 \times 2+0,80667 \varepsilon_{1}
$$

Persamaan struktural tersebut menunjukan bahwa nilai koefisien berpengaruh Citra merek (X1) terhadap kepuasan pelanggan (Y) sebesar 0,399 Kepercayaan merek (X2) terhadap kepuasan pelanggan (Y) sebesar 0,272.

Persamaan struktural kedua:

$Z=\boldsymbol{\rho z y} \mathbf{Y}+\epsilon_{2}$

\begin{tabular}{|c|c|c|c|c|c|}
\hline \multirow{2}{*}{ Model } & \multicolumn{2}{|c|}{$\begin{array}{c}\text { Unstandardized } \\
\text { Coefficients }\end{array}$} & \multirow{2}{*}{$\begin{array}{c}\text { Standardized } \\
\text { Coefficients }\end{array}$} & \multirow{2}{*}{$\mathrm{t}$} & \multirow{2}{*}{ Sig. } \\
\hline & $\mathrm{B}$ & Std.Error & & & \\
\hline Citra Merek (X1) & -113 & .139 & -085 & -813 & 0,418 \\
\hline Kepercayaan Merek (X2) & .598 & .138 & 0,435 & 4.323 & 0,000 \\
\hline Kepuasan Pelanggan (Y) & .475 & .142 & 0.337 & 3.334 & 0,001 \\
\hline $\begin{array}{lr}\mathrm{R} & =0,61 \\
\mathrm{R} \text { Square } & =0, \\
\text { Adjusted R Square } & =0 \\
\text { Dependent Variabel: Loyali }\end{array}$ & rek & & & & \\
\hline
\end{tabular}

Hasil analisis regresi untuk persamaan struktural kedua disajikan pada tabel berikut ini:

Tabel 3

Hasil Regresi Persamaan Struktural Terhadap Loyalitas Merek (Z)

Sumber: Data Primer Diolah

Pengaruh kesalahan pengganggu atau error variabel $\left(\rho \varepsilon_{2}\right)$ untuk persamaan struktural kedua diperoleh:

$$
\begin{aligned}
& \mathrm{P} \varepsilon_{2}=\sqrt{1-R^{2}} \\
& \sqrt{1}-0,618 \\
& =0,78617
\end{aligned}
$$

Persamaan struktural kedua diperoleh:

$$
\mathrm{Z}=\mathbf{- 0 8 5} \mathrm{X1}, \mathbf{0 , 4 3 5} \mathrm{X2}, \mathbf{0 , 3 3 7} \mathrm{Y}+\mathbf{0 , 7 8 6 1 7} \varepsilon_{2}
$$

Struktural tersebut menunjukan bahwa nilai koefisien berpengruh Citra Merek (X1) terhadap Loyalitas Merek sebesar -085 Kepercayaan Merek (X2) terhadap Loyalitas Merek sebesar 0,435 dan Kepuasan Pelanggan (Y) terhadap Loyalitas Merek sebesar 0,337.

\section{Pembahasan}

a. Pengaruh citra merek (X1) terhadap kepuasan pelanggan (Y) sebesar 0,399. Berdasarkan koefisien pengaruh tersebut dapat dinyatakan bahwa naik turunnya kepuasan pelanggan ditentukan oleh citra merek adalah sebesar $1,592 \%$ yang diperoleh dari rumus $(0,399)^{2} \times 100 \%=1,592 \%$.

b. Pengaruh kepercayaan merek (X2) terhadap kepuasan pelanggan (Y) sebesar 0,272. Berdasarkan koefisien pengaruh tersebut dapat dinyatakan bahwa naik turunnya kepuasan pelanggan ditentukan oleh kepercayaan merek adalah sebesar $0,073 \%$, yang dipeoleh dari rumus $(0,272)^{2} \times 100 \%=$ $0,073 \%$.

c. Pengaruh citra merek (X1) terhadap loyalitas merek (Z) sebesar -085. Berdasarkan koefisien pengaruh tersebut dapat dinyatakan bahwa naik turunnya loyalitas merek ditentukn oleh citra merek adalah sebesar $7,225 \%$, yang diperoleh dari rumus $(-085)^{2} \times 100 \%=7,225 \%$ 
d. Pengaruh kepercayaan merek (X2) terhadap loyalitas merek (Z) sebesar 0,435 Berdasarkan koefisien pengaruh tersebut dapat dinyatakan bahwa naik turunnya loyalitas merek ditentukan oleh kepercayaan merek adalah sebesar $189,2 \%$ yang dipeoleh dari rumus $(0,435)^{2} \times 100 \%=0,189 \%$.

e. Pengaruh kepuasan pelanggan (Y) terhadap loyalitas merek (Z) sebesar 0,337. Berdasarkan koefisien pengaruh tersebut dapat dinyatakan bahwa naik turunnya loyalitas merek ditentukan oleh kepuasan pelanggan adalah sebesar $0,113 \%$, yang dipeoleh dari rumus $(0,526)^{2} \times 100 \%=0,113 \%$.

\section{KESIMPULAN DAN SARAN}

\section{Kesimpulan}

1. Citra Merek memiliki pengaruh dalam meningkatkan Kepuasan Pelanggan sepeda motor merek Honda.

2. Kepercayaan Merek memiliki pengaruh dalam meningkatkan Kepuasan Pelanggan pada sepeda motor merek Honda.

3. Citra Merek tidak memiliki pengaruh terhadap Loyalitas Merek sepeda motor merek Honda.

4. Kepercayaan Merek memiliki pengaruh dalam meningkatkan Loyalitas Merek.

5. Kepuasan Pelanggan memiliki pengaruh dalam meningkatkan Loyalitas Merek.

\section{Saran}

1. Disarankan kepada perusahaan sepeda motor merek Honda agar memiliki lebih banyak variasi atau tampilan dibandingkan dengan sepeda motor merek lainnya.

2. Terdapat beberapa pelanggan yang belum memiliki pengalaman menggunakan berbagai tipe sepeda motor merek Honda.

3. Terdapat beberapa pelanggan belum merasa puas terhadap kinerja perusahaan dalam memproduksi sepeda motor merek Honda.

4. Disarankan kepada perusahaan agar membuat strategi sebaik mungkin sehingga konsumen selalu ingin membeli atau mengganti kendaraan dengan memilih sepeda motor merek Honda.

5. Bagi peneliti sealanjutnya yang ingin meneliti atau melanjutkan penelitian ini, disarankan untuk meneruskan atau mengembangkan penelitian ini dengan mencari faktor lain yang dapat mempengaruhi kepuasan pelanggan dan loyalitas merek. Perluasan penelitian juga dapat dilakukan dengan meningkatkan jumlah sampel dan penarikan sampel secara probabilitas.

\section{REFERENSI}

Aaker, David, (2009).“ Strategic Market Management”, (Fouth ed,): John Wiley \& Sons, Inc.

Assael, H. (1998). Consumer Behavior And Marketing Action $6^{\text {th }}$ edition. New York : International Thomson Publishing.

Chaudhuri, A and Holbrook, M.B. (2001). " The Chain Of Effects From Brand Trust And Brand Affect To Brand Performance: The Role Of Brand Loyalthy", Journal Of Marketing, Vol.65, No.2, pp.81-93.

Chi, H, K., Yeh, H.R., \& Chiou C, Y. (2009). The Effects Of Brand Affect On Female Cosmetic Users Brand Loyalty In Taiwan. The Journal Of American Academy Of Business, vol.14, No.2, Hal. 230-236.

Dutka, Alan. (1994). AMA Hand Book for Customer Satisfaction, NTC Bussiness Book, Lincolnwood, Illinois.

Ekasari, Novita. (2014). Pengaruh Promosi berbasis Social media Terhadap Keputusan Pembelian Produk Jasa Pembiayaan kendaraan PT. BFI Finance Jambi. Jurnal Volume.16, Nomor.2, Hal. 81-102, ISSN: 0852-8349. Universitas Jambi.

Fornell, C. (1996). "The American Customer Satisfaction Index: Nature, Purpose, and Findings", Journal of Marketing, Vol.60, Nomor.5, Hal 7-18. 
Griffin, Jill. (2005). Customer Loyality. Edisi Revisi dan Terbaru. Jakarta: Erlangga.

J. Setiadi, Nugroho, SE., MM., 2003, Perilaku Konsumen. Jakarta: Kencana.

Kotler, Philip, dan Gary Amstrong, 2009, Prinsip-Prinsip Pemasaran, Edisi 12, Jilid 2, Jakarta: Erlangga.

Kotler, Philip, dan Kevin Lane Keller.(2009). Manajemen Pemasaran. Jilid 1. Edisi Ke 13. Jakarta: Erlangga.

Kotler, Philip, dan Kevin Lane Keller. (2012). Marketing Management 13. New Jersey: Pearson Prentice, Hall, Inc

Kotler, Philip, dan Kevin Lane, Keller. (2013). Manajemen Pemasaran, Jilid 1, Edisi 13. Jakarta: Erlangga.

Lau, Gale dan Lee, S. (2000). Costumer Trust in a brand and Link to Brand Loyalthy. Journal Of Market Focused Management, Vol. 4, pp. 341-70.

Lupiyoadi, Rambat. 2001. ManajemenPemasaran Jasa :TeoridanPraktik, EdisiPertama, CetakanPertama, Jakarta. SalembaEmpat.

Mowen, John, C dan Michael Minor. (2002). Perilaku Konsumen. Jilid Kedua. Jakarta: Erlangga.

Peter, J. Paul dan Jerry C Olson. (2002). Perilaku konsumen dan strategi pemasaran. Terjemahan. Jakarta: Erlangga.

Ratri, Lutiary, Eka, (2007). Hubungan Antara Citra Merek (Brand Image) Operator Seluler Dengan Loyalitas Merek (Brand Loyalty) Pada Mahasiswa Pengguna Telepon Seluler Di Fakultas Ekonomi Regular Universitas Diponegoro Semarang, Fakultas Psikologi , Undip, Semarang.

Riduwan \& Kuncoro. (2007). Cara menggunakan dan memaknai Analisis Jalur (path analysis). Bandung: Alfabeta.

Sasongko, Jati dan Santoso, Dwi Budi (2008). 'konsep dasar SMS gateway dan aplikasi SMS menggunakan visual basic 6 dan FBUS lite'. Jurnal Teknologi Informasi, vol. 13, no 1. Hal.16.

Simamora, Bilson, (2003). Memenangkan Pasar dengan Pemasaran Efektif dan Profitable. Jakarta. Gramedia Pustaka Utama.

Sugiyono. (2014). Metode Penelitian Administrasi. Bandung: Alfabeta.

Surachman S.A,, (2008). Dasar-dasar manajemen merek, Bayumedia, CV,Malang Simamora, Bilson, 2003. Memenangkan Pasar dengan Pemasaran Efektif dan Profitable. Jakarta: Gramedia Pustaka Utama.

Tjahyadi, Rully, Arlan. (2006). Brand trusth Dalam Kontek Loyalitas Merek : Peran Karakteristik Merek, Karakteristik Perusahaan Dan Karakteristik Hubungan Pelanggan Merek. Jurnal Manajemen, Vol.6, No.1, P. 63-76.

Tjiptono, Fandy (2008). Service Management. Mewujudkan Layanan Prima. Yogyakarta: Andi Offset. Tjiptono, Fandy (2014). Pemasaran Jasa. Prinsip, Penerapan, Penelitian. Yogyakarta. Andi Offset. Wilkie, Wiliam. L. (1994). Consumer Behavior, 3rd ed. New York: John Wiley \& Sons 